UDK 528.946

\title{
SPATIAL ANALYSIS OF FIRES IN VILNIUS CITY IN 2010-2012
}

\author{
Darius VASILIAUSKAS ${ }^{1}$, Giedrè BECONYTE் ${ }^{2}$ \\ Centre for Cartography, Vilnius University, \\ M. K. Čiurlionio g. 21, LT-03101 Vilnius, Lithuania \\ E-mails: ${ }^{1}$ vasiliauskas.drs@gmail.com (corresponding author); ${ }^{2}$ giedre.beconyte@gf.vu.lt
}

Received 24 June 2014; accepted 9 March 2015

\begin{abstract}
The paper describes the results of investigation into urban fires in the city of Vilnius, Lithuania in the three-year period of 2010-2012. Cartographic and geospatial analysis of fires is needed due to dynamism of this phenomenon, risks for inhabitants, importance to city's socio-economic development and lack of geographic approach to research of urban fires in Lithuania. The registered fires were mapped and grouped by their type (abandoned building fires, open space fires, fires in tower blocks of flats, garbage can fires, vehicle fires and arsons), cause, location type (open space and premises) and by fatality rate. Spatial distribution of fires at different scales was analysed using cartographic method and spatial analysis with GIS. Some unexpected patterns have been revealed, analysed and compared with building materials that dominate in different areas of the city. It was found out that relative frequency of fires depends on complex parameters of socio-demographic environment whereas constructional materials have little or no impact. We expected to observe a relationship between criminal activities and fires due to similar influencing socio-demographic factors. Positive correlation, though insignificant, supported this hypothesis. The study showed that fire distribution patterns may be very specific for an individual city and difficult to explain by general assumptions. Different methods of spatial, statistical and cartographic analysis must be combined in order to make reliable generalisations.
\end{abstract}

Keywords: urban fires, spatial distribution, constructions, constructional materials, crimes.

\section{Introduction}

First investigations on urban fires started in the USA in the 1980s. They mainly concentrated on impact of demographic and socio-economic factors on fire risk. (Sternlieb, Burchell 1973; Bertrand, Lawrence 1976; Karter et al. 1977, 1978; USFA 2004, 2009). 21st century brought more studies in Europe (Corcoran et al. 2007a, 2007b; Špatenkova, Stein 2010), Asia (Urban Research Institute 2004; Nisanci 2010; Zhao 2011; Lu et al. 2013), Australia (Corcoran et al. 2009; Chhetri et al. 2009; Sufianto, Green 2012). A number of them applied spatial and temporal analysis and resulted in prognostic maps (Corcoran et al. 2009; Wu 2007; Rohde et al. 2010; Zhao 2011) and mathematical models (Wu, Ren 2009; Ceyhan et al. 2013; Zhang 2013).

Analysis of location and dynamics of fires allows for revealing the trends of spatio-temporal concentration of fires (Corcoran et al. 2009). Based on this information more efficient prevention strategies and measures can be applied thus saving money and lives (according to official statistics of Fire and Rescue Department 3065 persons died and 3112 were injured in Lithuania during the analysed three-year period). Urban fires are as often as the countryside fires but the major causes are different: the most of the fires in countryside are caused by improper electric installation and ovens, lightning whereas urban fires strongly depend on social factors. Urban fires in Vilnius, although they only comprise about $15 \%$ of all insurance events, cause biggest damage to households and often result in fatalities. The number of fires in the city does not decrease: we have analysed 1506 events in 2010, 1715 events in 2011 and 1303 events in 2012. In the research carried out in early 2013 we attempted to identify the most problematic areas at the scale of city ( $500 \times 500$ meter cells) and to analyse the structure of fires in those areas at larger scale.

Different researchers have identified some common factors that influence the risk of fires. Munson (1976) has demonstrated almost linear dependence 
between the number of fires and population density and reverse linear dependency between the number of fires and household income. Although it was based on small number of events, later research confirmed those two factors, especially the level of income (Gunther 1981; Munson, Oates 1983; Fahy, Norton 1989; Jennings 1996; Špatenkova, Stein 2010). The other social factors that doubtlessly have impact on increased risk of urban fires are: high unemployment rate (Munson, Oates 1983; New South Wales Fire Brigades 1997; Chhetri et al. 2009); high percentage of incomplete (one parent) or unstable families (Schaenman et al. 1977; Karter et al. 1978; Jennings 1996; Leth 1998; Chhetri et al. 2009); low level of education (Schaenman et al. 1977; Munson, Oates 1983; Corcoran et al. 2011); age of population especially the rate of very young (Runyan et al. 1993; New South Wales Fire Brigades 1997; Chhetri et al. 2009) or elderly people (Jennings 1996).

Later studies (Yamashita 2008; Špatenkova, Stein 2010) revealed some significant factors related with urban environment: technogenic development, age and type of buildings and ratio of parcels without owners; and temporal variations (Corcoran et al. 2007a, 2009).

Some authors have determined dependencies between frequency of fires and characteristics of urban communities. Hall (1993) stated that there exists a non-linear dependence: both small and large communities are exposed to higher fire risk than average size communities (likely due to hypothetically lower rate of inhabitants with low income in the latter). As our data showed some concentrations of fires unexplained neither by population density nor by above listed factors alone, we analysed them against two other phenomena that could possibly have impact on fire risk: prevailing constructional materials as urban environment criterion and crime rate as a social criterion. Both datasets were analysed with absolute and relative (number of fires per 1000 inhabitants) fire density grid data and spatial dataset of registered fire events.

\section{Fires in Vilnius in 2010-2012}

The 4524 fires in Vilnius City in 2010-2012 have been uniformly registered with the following attributes: full date, time (hour and minutes) address, type of object, cause of fire, number of saved people and number of fatalities. The data were geocoded and for comparison purposes generalised by statistical grid at resolution $500 \times 500$ meter. Relative number of fires was calculated using the data of officially registered residents for the address points. The fires in open areas comprise $26.5 \%$, garbage container fires - $18.4 \%$, fires in tower blocks of flats $-18.1 \%$, vehicle fires $-13.5 \%$, fires in abandoned buildings $-8.7 \%$ and fires in private houses - only $4.1 \%$. The main reasons of fires are: negligence $(70.3 \%)$, arsons (7\%) and faults of electric installations (buildings $-6.5 \%$ and vehicles $-6.2 \%)$.

General fire density maps look very similar to population density maps, though correlation between the number of residents and residential fires is barely significant $(r=0.55)$. It was unexpected to observe correlation between the number of residents and open space fires is $(r=0.36)$.

Number of fires per 1000 inhabitants shows different pattern (Fig. 1), not very different from the pattern of fires per building (kc.gf.vu.lt/Publikacijos/Gaisrai/BuildingFR.jpg). We assume that larger zones where the concentration is much higher than average reflect abandoned buildings are characterized either by high percentage of abandoned buildings/flats, like those in at Vilnelè river and (or) by communities/families at risk, like Naujininkai and the permanent gypsy camp or particular suburban residential cottage areas.

The temporal patterns are also clearly distinguishable and very similar for each year (kc.gf.vu.lt/Publikacijos/ Gaisrai/FireByTime.jpg). Significantly more fires occur in April (most likely related to dry weather conditions and burned grass) and in October-November when the heating season starts and most of extra fires are due to improper use and (or) faults of heating equipment. The 'worst' are the afternoon hours, mainly after 14 PM whereas low numbers of fire incidents are registered between 5 and 10 AM. Among days of the week, significantly more events occur on Sundays

Different types of fires occur in the districts of the city with different characteristics. It can be demonstrated by the location quotient maps ( $k c . g f . v u . l t$ ) Publikacijos/Gaisrai/LQs.jpg). Typically prevailing fire incidents are related with the dominance of specific target territories: blocks of flats, open (but not recreational) spaces, abandoned buildings. Fires in garbage containers prevail in districts with lower social standard (e.g., Šnipiškès, Naujamiestis) and the central districts where they may be due to higher number of homeless people. Arsons dominate in the rather prestigious districts of Žvèrynas and Antakalnis. Considering this, different fire prevention measures should be planned in those districts. There is a single zone where deconcentration of fires was observed in the northern part of Naujoji Vilnia that could be explained by improving socio-economic environment in this district. 


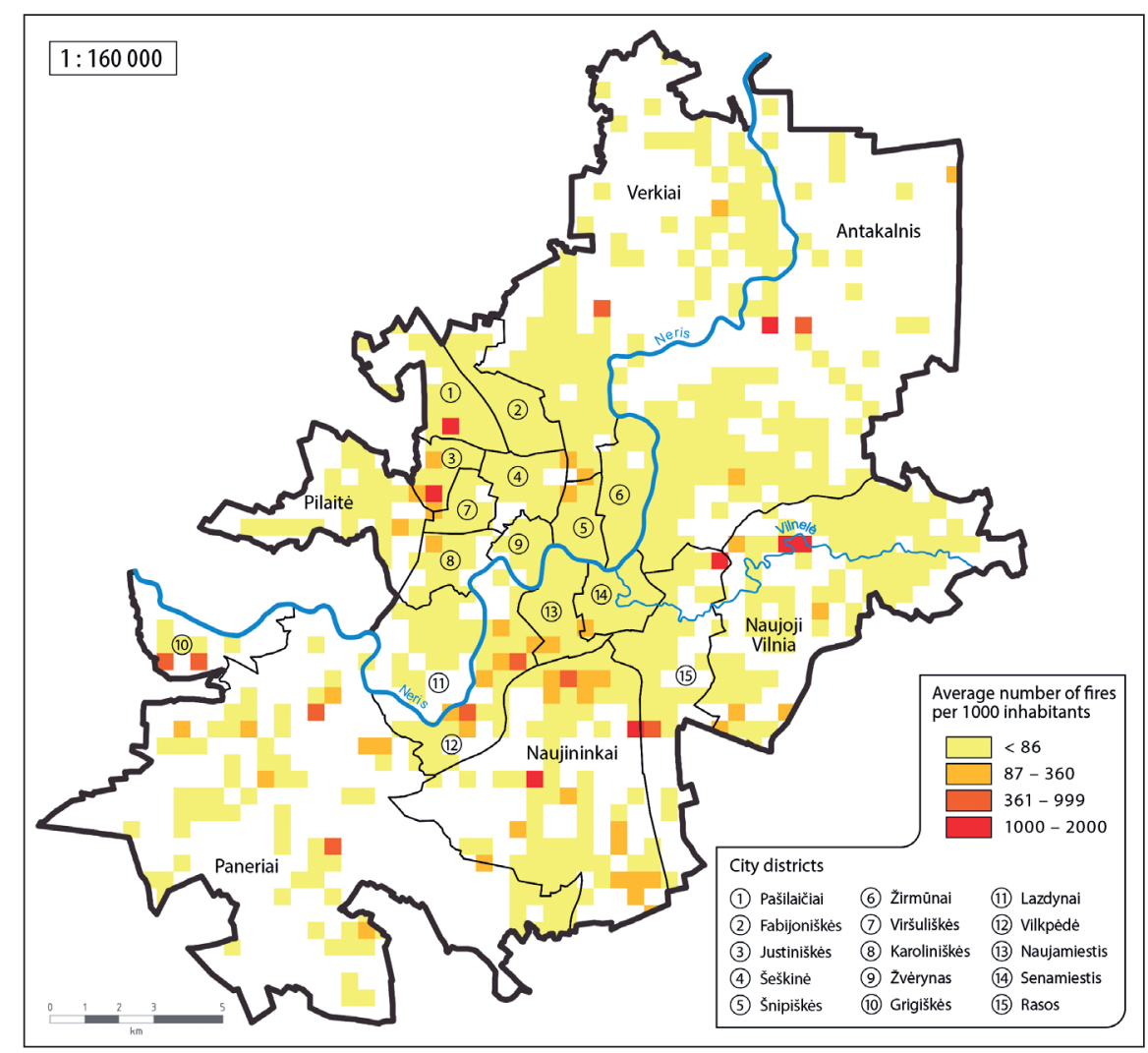

Fig. 1. Average number of fires per 1000 inhabitants in 2010-2012

\section{Fires and crimes}

Based on hypothesis that both criminal activity and fires reflect a whole complex of social factors, we combined fire data with data on registered criminal events registered during 2012, provided by the Vilnius police authorities. Criminal incidents that are presumably not related to the urban environment (e.g., forgery, bribery, tax evasion, unauthorized access to information etc.) were excluded and the remaining 2063 incidents were grouped by the type of environment: open spaces and other public areas; residential premises; non-residential premises. Even though both criminal incidents and fires expectedly strongly depend on similar socio-demographic reasons, correlation between them in the territory of Vilnius reaches only 0.44 (cells without fire incidents are ignored) that is not significant. Correlation between fires and all registered events that have not been qualified as criminal incidents (noise, minor vandalism, harassment etc.) is slightly higher -0.51 (cells without fire incidents are ignored).

The map (Fig. 2) depicts the ratio of fire and crime events. It shows the 'central' cluster of lower fireto-crime rate in densely populated city areas. There are some spots of higher than average concentration of both crimes and open space fires (e.g., at the border of Fabijoniškès, Šeškinè and Pašilaičiai) and that may indicate activities of youngster gangs. The cells with higher than average ratio, caused by other than demographic factors, are scattered in the peripheral districts. There are two main types of them: areas that contain higher percent of non-residential constructions and abandoned buildings and small residential cottage areas with unsafe neighbourhood. Garbage container fires dominate in such cells close to the centre. In some densely populated cells where garbage container fires occur systematically (mainly due to vandalism and negligence), plastic containers should be replaced by metallic ones.

\section{Fires and constructional materials}

Digital database of constructional materials of Vilnius buildings has been compiled based on realty register data and on data provided by Vilnius municipality (Jukna 2014). Vilnius city consists of variety of relatively homogeneous zones where at least $60 \%$ of buildings are built using the same basic constructional material: brick constructions in the Old Town (20.7\%), surrounded by the concrete blocks of flats of 1970s-1980s (34.8\%), wooden house mainly in districts in Žverrynas, Antakalnis and Naujoji Vilnia (16.9\%); scattered peripheral newer 


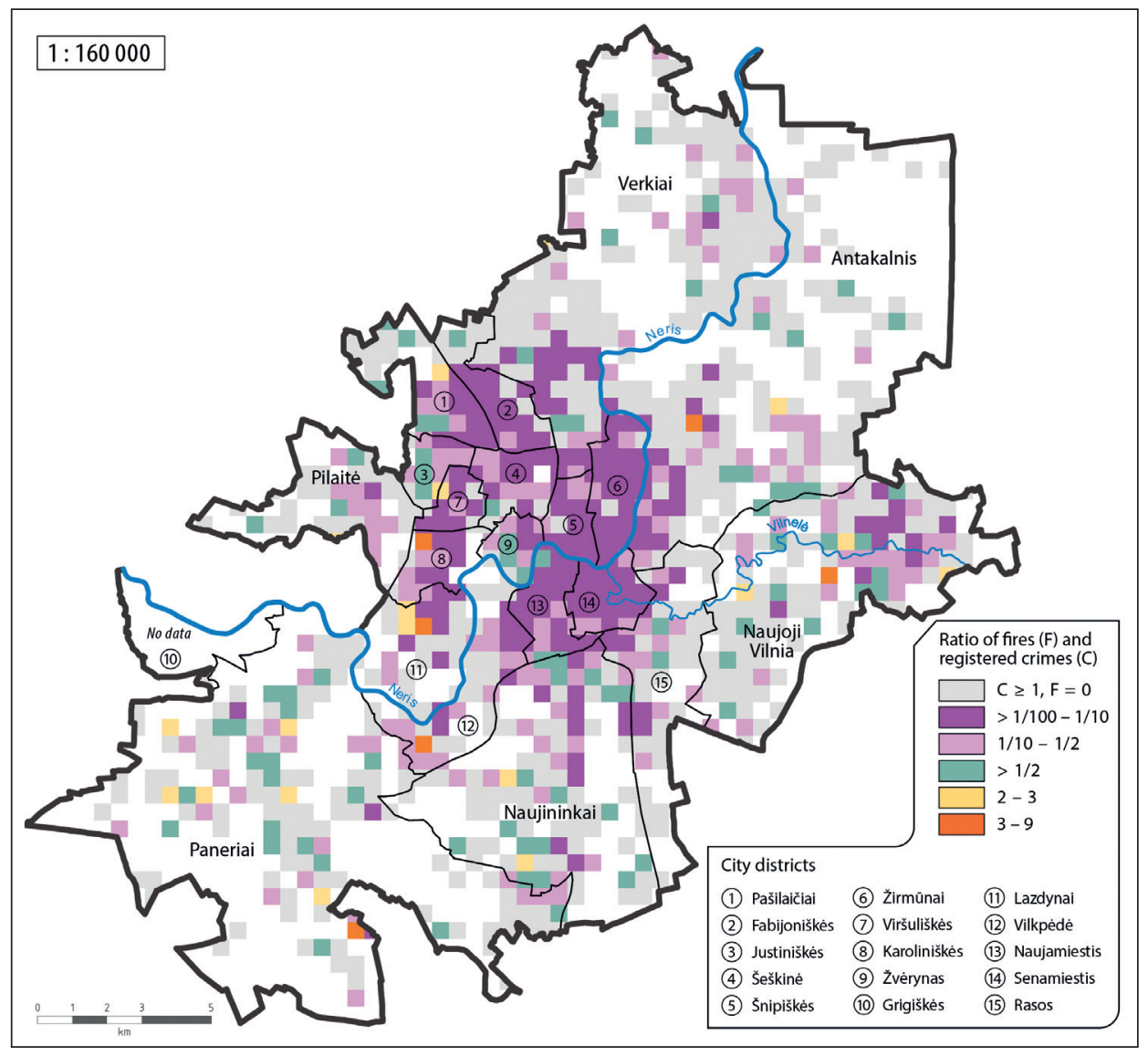

Fig. 2. Fires vs. registered crimes in 2012

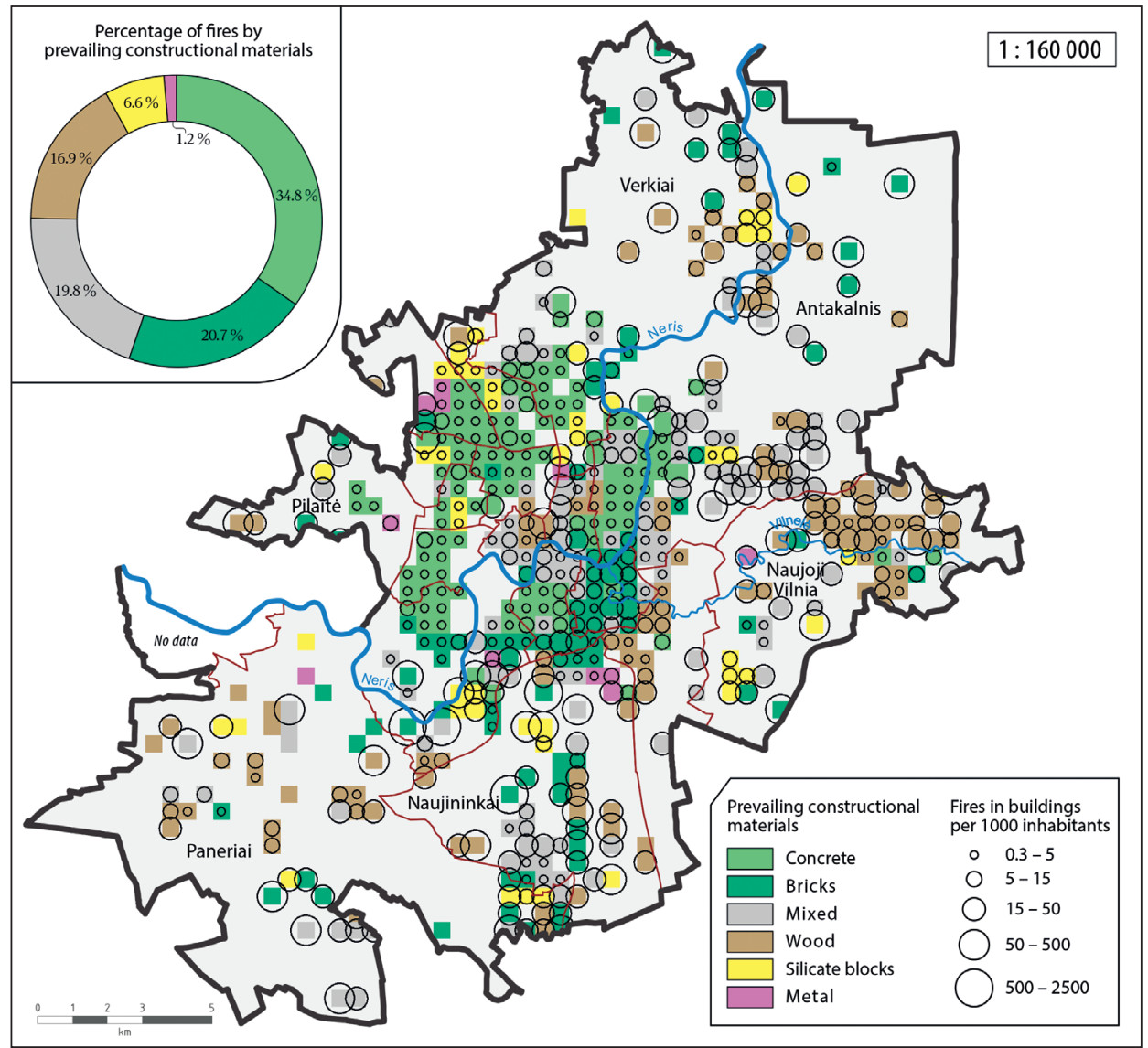

Fig. 3. Fires vs. constructional materials in 2010-2012 
silicate block areas and $19.8 \%$ of 'mixed' areas (two or three materials, at least $25 \%$ each).

The chart (Fig. 3) demonstrates that relative number of fires is much lower in the concrete and silicate block areas. More fires per resident occur in areas of older brick dwellings and even more, as it could have been expected, in the areas with prevailing wooden constructions - both with high percentage of dilapidated buildings without central heating. It is often believed that arson is most common cause of fires in the 'wooden' districts of Vilnius, but the data does not confirm it.

Fires in the mixed type built-up areas are not directly related to the number of residents, they often occur in warehouses, abandoned buildings etc., but very rarely in metallic constructions.

\section{Other insights and conclusions}

Urban fires in the city of Vilnius occur in similar yearly spatial and temporal patterns. Number of fires depends on various technological, socio-demographic and environmental factors that are interrelated. Therefore it is practically impossible to determine impact of a single factor, but GIS analysis allows to identify territories at risk and to make assumptions about the reasons that is necessary for efficient fire prevention.

Fire incidents in Vilnius are related with population density and urbanization level. Number of permanent residents significantly influences the number of residential fires in densely populated districts and much less in larger industrial districts. It was a surprise to find out that the number of fires does not correlate with the density of buildings in Vilnius, but some negative correlation is observed in some districts i.e., less fires occur in densely built-up parts of Karoliniškès $(\mathrm{r}=-0.61)$, Žvèrynas and Pilaitè $(\mathrm{r}=-0.41)$. Considering the diversity of the three districts (old and new private houses of Žvėrynas, soviet blocks of flats of Karoliniškès and new blocks of flats in Pilaitè), it could only be explained by presence of small active communities preventing residential fires in those districts.

Location quotient maps show general dependence between percentage of target territories / social groups and number of fire incidents. It should be noted that the biggest numbers of fires that are due to negligence are evenly close to average in all the districts.

Hot-spot analysis shows four significant (99.7\%) clusters with increasing risk of fires ( $k c . g f . v u . l t$ ) Publikacijos/Gaisrai/HotSpots.jpg): two residential areas where most of fires occur in flats and garbage containers (western part of Karoliniškès and northern part of Justiniškès) and two industrial areas in Naujininkai (mainly fires in open areas and abandoned buildings). Some of the hot-spots may be explained by proximity to specific objects, or, in contrast, by peripheral location.

As it was demonstrated by our research, the assumptions drawn from data not only support but also may contravene common beliefs and hypotheses about risk and reasons of urban fires. Further detailed analysis of detected territorial anomalies is necessary in order to integrally understand fire patterns in each individual city.

\section{References}

Bertrand, L.; Lawrence, M. S. 1976. The human factor in high fire risk urban residential areas: A Pilot Study in New Orleans, Louisiana. Washington, DC: U.S. Department of Commerce, National Fire Prevention and Control Administration.

Ceyhan, E.; Ertugay, K.; Duzgun, S. 2013. Exploratory and inferential methods for spatio-temporal analysis of residential fire clustering in urban areas, Fire Safety Journal 58: 226239. http://dx.doi.org/10.1016/j.firesaf.2013.01.024

Chhetri, P.; Corcoran, J.; Stimson, R. J.; Inbakaran, R. 2009. Modelling potential socio-economic determinants of building fires in South East Queensland, Geographical Research 48(1): 75-85.

http://dx.doi.org/10.1111/j.1745-5871.2009.00587.x

Corcoran, J.; Higgs, G.; Brunsdon, C.; Ware, A. 2007. The use of comaps to explore the spatial and temporal dynamics of fire incidents: a case study in South Wales, United Kingdom, The Professional Geographer 59(4): 521-536.

Corcoran, J.; Higgs, G.; Brunsdon, C.; Ware, A.; Norman, P. 2007. The use of spatial analytical techniques to explore patterns of fire incidence: a South Wales case study, Computers, Environment and Urban Systems 31: 623-647.

http://dx.doi.org/10.1111/j.1467-9272.2007.00639.x

Corcoran, J.; Higgs, G.; Higginson, A. 2011. Fire incidence in metropolitan areas: a comparative study of Brisbane (Australia) and Cardiff (United Kingdom), Applied Geography 31: $65-75$.

http://dx.doi.org/10.1016/j.compenvurbsys.2007.01.002

Corcoran, J.; Higgs, G.; Rohde, D.; Chhetri, P. 2009. Investigating the association between weather conditions, calendar events and socio-economic patterns with trends in fire incidence: an Australian case study, Journal of Geographical Systems 13(2): 193-226. http://dx.doi.org/10.1007/s10109-009-0102-z

Fahy, R.; Norton, A. L. 1989. How being poor effects fire risk, Fire Journal 83: 28-36.

Gunther, P. 1981. Fire-cause patterns for different socio-economic neighborhoods in Toledo, OH, Fire Journal 75: 52-58.

Hall, J. R. 1993. The U.S. fire problem overview report through 1982: leading causes and other patterns and trends. Quincy, MA: National Fire Protection Association.

Jennings, R. 1996. Urban residential fires: an empirical analysis of building stock and socio-economic characteristics for Memphis, Tennessee: Doctoral dissertation. Cornell University, Ithaca, New York, USA. 
Jukna, L. 2014. Methodology of quantitative assessment of landscape technogeneity (case study of the largest cities of Lithuania): Doctoral dissertation. Vilnius University, Vilnius, Lithuania.

Karter, J.; Michael, J.; Donner, A. 1977. Fire rates and census characteristics: a descriptive approach. Boston: National Fire Protection Association.

Karter, J.; Michael, J.; Donner, A. 1978. The effect of demographics on fire rates, Fire Journal 72(1): 53-65.

Leth, P.; Gregersen, M.; Sabroe, S. 1998. Fatal residential fire accidents in the municipality of Copenhagen, 1991-1996, Preventive Medicine 27: 444-451. http://dx.doi.org/10.1006/pmed.1998.0295

Lu, L.; Peng, C.; Zhu, J.; Satoh, K.; Wang, D.; Wang, Y. 2013. Correlation between fire attendance time and burned area based on fire statistical data of Japan and China, Fire Technology, January, 1-22.

Munson, M. 1976. Residential fire and urban neighborhoods: an empirical analysis of Charlotte, North Carolina: Doctoral dissertation. Princeton University, New Jersey, USA.

Munson, M. J.; Oates, W. E. 1983. Community characteristics and the incidence of fire: an empirical analysis, in Rapkin, C. (Ed.). The social and economic consequences of residential fires. Lexington, MA: D.C. Heath and Co.

New South Wales Fire Brigades. 1997. Socio-economic characteristics of communities and fires. New South Wales Fire Brigades Statistical Research Paper, Issue 4/97.

Nisanci, R. 2010. GIS based fire analysis and production of firerisk maps: the Trabzon experience, Scientific Research and Essays 5(9): 970-977.

Rohde, D.; Corcoran, J.; Chhetri, P. 2010. Spatial forecasting of residential urban fires: a Bayesian approach, Computers, Environment and Urban Systems 34: 58-69. http://dx.doi.org/10.1016/j.compenvurbsys.2009.09.001

Runyan, C. W.; Bangdiwala, S.; Linzer, M.; Sacks, J.; Butts, J. 1993. Risk factors for fatal residential fires, Fire Technology 29(2): 183-193. http://dx.doi.org/10.1007/BF01038538

Schaenman, P.; Hall, J.; Schainblatt, A.; Swartz, J.; Karter, M. 1977. Procedures for improving the measurement of local fire protection effectiveness. Boston: National Fire Protection Association.

Špatenkova, O.; Stein, A. 2010. Identifying factors of influence in the spatial distribution of domestic fires, International Journal of Geographical Information Science 24(6): 841-858. http://dx.doi.org/10.1080/13658810903143634
Sternlieb, G.; Burchell, R. 1973. Fires in abandoned buildings, Fire Journal 67(2): 24-31.

Sufianto, H.; Green, A. R. 2012. Urban fire situation in indonesia, Fire Technology 48: 367-387. http://dx.doi.org/10.1007/s10694-011-0226-9

United States Fire Administration (USFA). 2004. Fire in the United States 1992-2001. 13th ed. Washington, DC: United States Fire Administration, National Fire Data Center.

United States Fire Administration (USFA). 2009. Fire in the United States 2003-2007. 15th ed. Washington, DC: United States Fire Administration, National Fire Data Center.

Urban Research Institute. 2004. Lao urban fire risk assessment mapping in Pakse City. Lao Urban Disaster Mitigation Project, Project completion report.

Wu, L.; Ren, A. 2009. Research on urban fire risk comprehensive evaluation and its applications in China, Human and Ecological Risk Assessment 15: 778-788. http://dx.doi.org/10.1080/10807030903051226

$\mathrm{Wu}, \mathrm{Z}$. 2007. The research on the potential analysis of urban fire incidents, in 2nd International Conference on Urban Disaster Reduction, 27-29 November 2007, Taipei, Taiwan:

Yamashita, K. 2008. Understanding urban fire: modeling fire incidence using classical and geographically weighted regression: Doctoral dissertation. University of Colorado, Denver, USA.

Zhang, Y. 2013. Analysis on comprehensive risk assessment for urban fire: the case of Haikou City, Procedia Engineering 52: 618-623. http://dx.doi.org/10.1016/j.proeng.2013.02.195

Zhao, S. 2011. Simulation of mass fire-spread in urban densely built areas based on irregular coarse cellular automata, Fire Technology 47: 721-749.

http://dx.doi.org/10.1007/s10694-010-0187-4

Darius VASILIAUSKAS. Student of Cartography, Master's Degree programme, Vilnius University, Faculty of natural Sciences. Bachelor's Degree in Geography, 2012, Vilnius University. His current research interests include use of geographic information systems (GIS) in geography, crime analysis with crime mapping and geography of crime.

Giedrė BECONYTÉ is Professor at the Centre for Cartography, Vilnius University. She has published more than 40 papers in scientific journals as well as conference proceedings and textbooks on spatial analysis and DBMS. Her current research interests include thematic mapping, geographic information system design and project management. 